DOI: https://doi.org/10.37816/2073-9567-2020-56-226-235

УДК $7.033+687.016$

ББК 85.126

This is an open access article distributed under

the Creative Commons Attribution 4.0

International (CC BY 4.0)

(C) 2020. Olga A. Kovtun

Chelyabinsk, Russia

\title{
THE ART OF CHURCH EMBROIDERY AND TRADITIONAL CULTURE: COMMON FEATURES
}

Abstract: The paper is to address little-studied pieces of goldwork church embroidery stored in the vestry of St. Simeon's Cathedral of Verkhoturye. The author's goal was to explore artistic crafts of women's monasteries and actualize the theme of church art in Russian culture. The sacred objects represent the most important part of the Eastern Christian cultural heritage. The study considers stylistic and decorative-artistic features of the works of liturgical embroidery in the $19^{\text {th }}$ century. The research methodology is based on the principle of integrated approach and the method of artistic and stylistic analysis. The goal of studying church monastic art at the turn of the $20^{\text {th }}$ century determined the methodology of research. The author considered religious objects as works of arts and crafts accessory in the liturgy. The artistic and stylistic method of analyzing works allowed highlighting the influence of secular and folk embroidery elements on the ornamentation of church embroidery. The combination of art history and historical approaches made it possible to identify the time frame and artistic features of the works in question in the context of art of the late $19^{\text {th }}$ century. The paper points out the connection between folk and religious and orthodox art in the spiritual culture of Russia. Moreover the study results in introducing of the little-known artifacts of church art into scientific circulation.

Keywords: church embroidery, goldwork, shroud, ornament, Eastern Christian culture. Information about the author: Olga $\mathrm{A}$. Kovtun - $\mathrm{PhD}$ in Philosophy, Associate Professor, The South Ural State University, Lenin Ave. 86, 454080 Chelyabinsk, Russia. ORCID ID: https://orcid.org/0000-0003-2609-5813. E-mail: ol.kowtun2012@yandex. $\mathrm{ru}$

Received: January 31, 2019

Date of publication: June 28, 2020

For citation: Kovtun O. A. The art of church embroidery and traditional culture: common features. Vestnik slavianskikh kul 'tur, 2020, vol. 56, pp. 226-235. (In English) DOI: https://doi.org/10.37816/2073-9567-2020-56-226-235 
г. Челябинск, Россия.

\title{
ИСКУССТВО ЦЕРКОВНОГО ШИТЬЯ И ТРАДИЦИОННАЯ КУЛЬТУРА: ОБЩИЕ ЧЕРТЫ
}

\begin{abstract}
Аннотация: В данной статье к исследованию привлечены малоизученные произведения церковного золотого шитья, хранящиеся в ризнице собора Святого Симеона Верхотурского г. Челябинск. Автор ставит своей задачей изучение художественных промыслов женских монастырей и актуализацию темы церковного искусства в российской культуре. Священные предметы представляют важнейшую часть восточнохристианского культурного наследия. В исследовании рассматриваются стилистические и декоративно-художественные особенности произведений литургического шитья в XIX в. В основе методологии исследования - принцип комплексного подхода, а также метод художественно-стилистического анализа. Методика исследования определялась задачей изучения церковного монастырского искусства на рубеже XIX-XX вв. Предметы культа рассмотрены как произведения декоративно-прикладного искусства, участвующие в литургии. Художественно-стилистический метод анализа произведений позволил выявить влияние элементов светской и народной вышивок на орнаментику церковного шитья. Сочетание искусствоведческого и исторического подходов позволило наиболее точно определить временные рамки и художественные особенности рассматриваемых произведений в контексте искусства конца XIX в. Отмечена связь народного и религиозно-православного искусства в духовной культуре России. Результатом исследования является введение в научный оборот малоизвестных памятников церковного искусства.
\end{abstract}

Ключевые слова: церковное шитье, золотное шитье, плащаница, орнамент, восточнохристианская культура.

Информация об авторе: Ольга Автономовна Ковтун - кандидат философских наук, доцент, Южно-Уральский государственный университет, пр-т Ленина, д. 86, 454080 г. Челябинск, Россия. ORCID ID: https://orcid.org/0000-0003-2609-5813. E-mail: ol.kowtun2012@yandex.ru

Дата поступления статьи: 31.01.2019

Дата публикации: 28.06.2020

Для цитирования: Ковтун О. А. Искусство церковного шитья и традиционная культура: общие черты // Вестник славянских культур. 2020. Т. 56. С. 226-235. DOI: https://doi.org/10.37816/2073-9567-2020-56-226-235

The revival of interest in Orthodox culture and "temple activity" in Russia sparked interest in pictorial embroidery, which plays an important role in the liturgical space of the Orthodox church. Interest within the art history field in religious art is growing as a result of art workshops specializing in the field of church embroidery.

Church embroidery has been well known in Europe since ancient times. The earliest surviving artifacts of church embroidery date back to the $10^{\text {th }}-12^{\text {th }}$ centuries. Having accepted Christianity from Byzantium, Rus adopted a divine service for which the use of fabrics was 
characteristic. Embroidery is stored in each temple in the form of liturgical objects, which are an integral part of the sacred space of the Eastern Christian church.

The period of the blossoming of church pictorial embroidery falls on the $15^{\text {th }}-16^{\text {th }}$ centuries. This flourishing was also due to the close connection of church embroidery with the traditional folk embroidery of the pre-Christian period. By absorbing the Byzantine traditions of church art, Russia clothed them in forms close to its original culture. It was in church embroidery that a truly popular understanding of beauty was manifested. It should be clarified that the term "embroidery" was used in Russia until about the $18^{\text {th }}$ century for all types of needlework. Now embroidery refers to ancient Russian and Western European embroidery with gold, silver and colored silk threads with pearls and other stones on church vestments, shrouds, festive robes [2].

The changes connected with the reforms of Peter I changed the state, everyday life, and church life. The process of secularization of culture that he initiated led to the decline of gold embroidery workshops of the Grand Duchesses, which were closely connected with the way of life of noble women. Interest in the church embroidery works appeared among collectors of antiquities in the second half of the $19^{\text {th }}$ century alongside growing interest in the study of Russian iconography. Embroidery works were found in the private collections of Count A. S. Uvarov, P. I. Shchukin and others. This period began the history of the study of church embroidery.

Among foreign researchers of Christian shrines, certain fundamental works should be noted: those of P. Brown, H. Belting, and M. M. Gauthier. An example study of Serbian embroidery are the works of L. Mirkovich. Contributions to the study of ancient Russian embroidery were made by: E. V. Georgievskaya-Druzhinina, I. I. Vishnevskaya, L. D. Likhacheva, N. A. Mayasova, T. N. Manushina, A. N. Svirin, and A. V. Silkin.

However, the study of ancient Russian embroidery was carried out on artifacts of the golden period of the art of pictorial embroidery of the $16^{\text {th }}$ century, while works of church

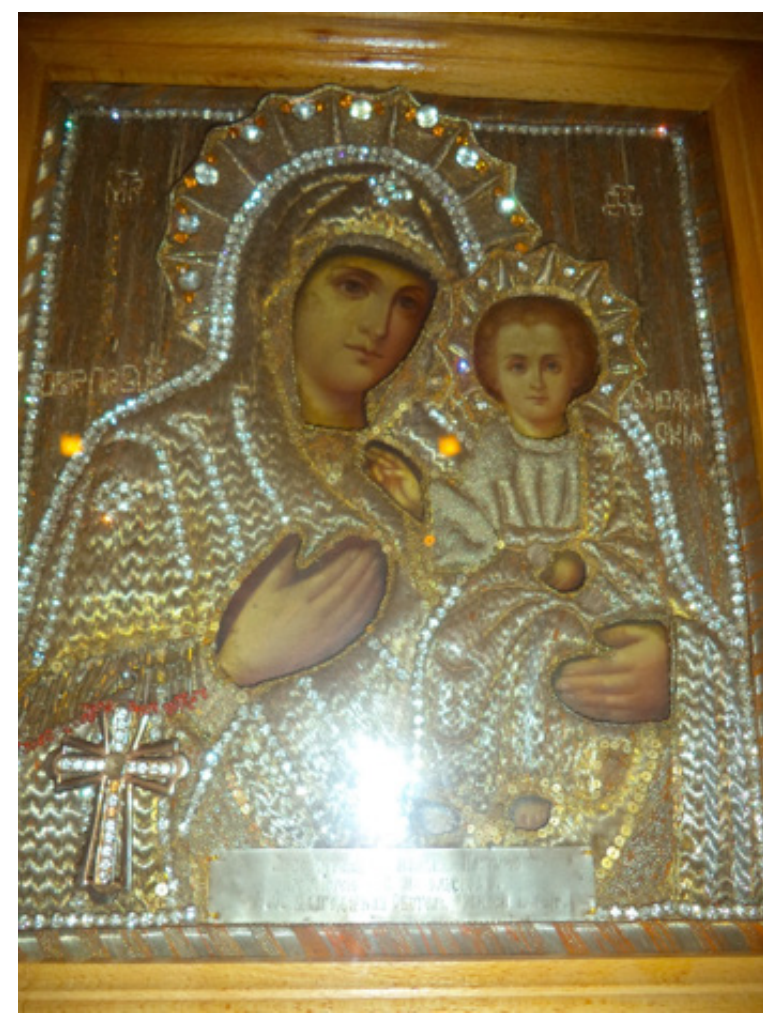
ornamental embroidery of the $19^{\text {th }}$ century are left untouched by researchers.

Church embroidery was divided into two types: pictorial and ornamental. "Pictorial embroidery is one of the types of icon painting, performed with colored thread on fabric (silk, satin, and damask) reproducing the image of the saint, the twelve-day festivities, and the events of the Holy Week, besides silk, threads of gold and silver, pearls, precious stones are used in pictorial embroidery" [2, p. 739].

Рисунок 1 - Одигитрия Казанская (шитый оклад). 1911. (ткань, шитье по карте, золотая нить, канитель, трунцал, ограненные стекла). 39х34. Челябинск.

Храм Св. Симеона Верхотурского Figure 1 - Hodegetria of Kazan (sewn vestment). 1911. (fabric, embroidery on board, gold thread, gimp, gold lace, faceted glass.). 39x34 Chelyabinsk. Temple of St. Simeon of Verkhoturye 
Thus, pictorial embroidery represents a synthesis of icon painting, calligraphy, and embroidery and reflects the stylistic features of painting of a particular historical period. The correspondence between the art of embroidery and icon painting has been emphasized by many authors. Its similarity with iconography is also emphasized by the presence of the centerpiece and edging in embroidery items, similar to the iconic ark. At the same time, embroidery work are subject to different aesthetic laws and have their own specifics.

The name "pictorial" is appropriated to this art form, as depictive work, as opposed to ornamental embroidery $[5$, p. 5].

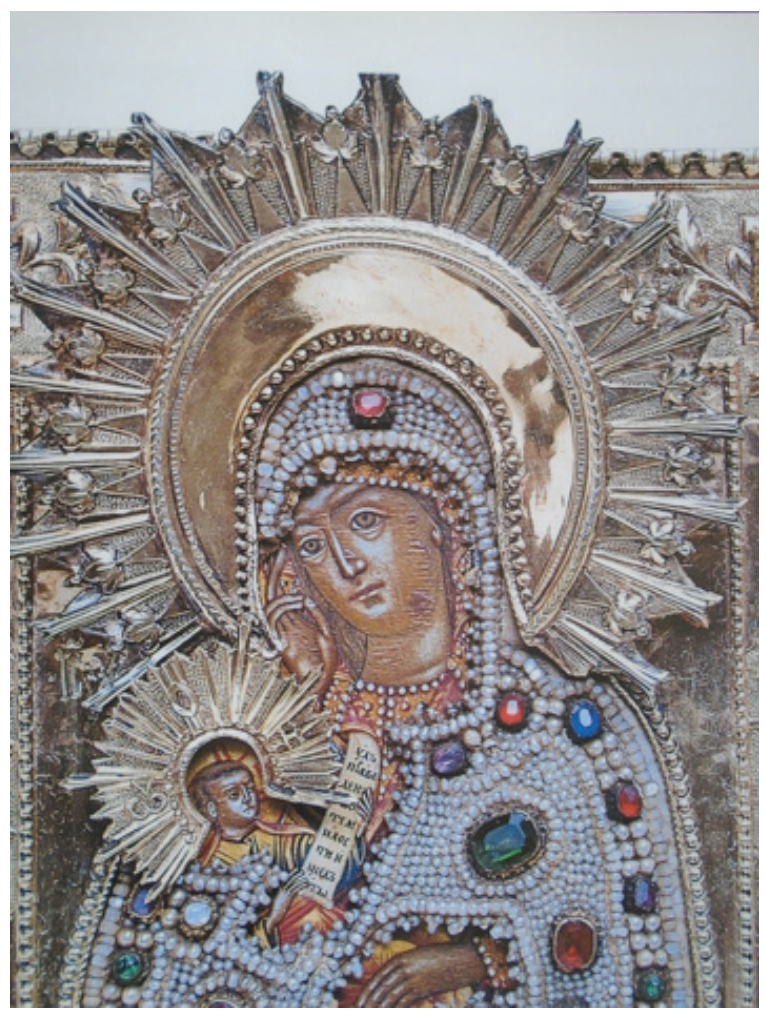

Рисунок 2 - Богоматерь «Утоли мои печали» (в окладе и шитой ризе). Риза: 1883 (ткань, шитье по карте, бисер, жемчуг, стекла). 17.5x15.8x2.2. Екатеринбург Figure 2 - Our Lady "Soothe My Sorrows" (in metal cover and robe). Riesa: 1883 (fabric, embroidery on board, beads, pearls, glasses). 17.5x15.8x2.2. Ekaterinburg

Ornamental church embroidery, the development of which began in the $17^{\text {th }}$ century, are compositions consisting of figurative elements of symbolic significance created using embroidery on church textiles. Ornamental embroidery is used as an independent kind of embroidery and as a background for pictorial embroidery. Unlike pictorial embroidery, which obeys the canon, the ornamental style developed more freely. Whereas ornamental embroidery was available to all segments of the population, pictorial embroidery was an elite art. The techniques and methods of ornamental embroidery used changed throughout the development of this ancient type of applied art, and the ratio of pictorial and ornamental embroidery in the objects of the church also changed. Pictorial embroidery in the $14^{\text {th }}$ and $15^{\text {th }}$ centuries leans toward toward painting, and in the $17^{\text {th }}$ century, gold was intensively used to create ornamental compositions to enhance decorative art. Beginning in the $14^{\text {th }}$ century, pure gold would be replaced with gilded silver, which is called "goldwork". Embroidery with 
pearls and gold (drawn, scanned or spun) threads was supplemented with precious stones and reflected the aesthetic ideals of the $17^{\text {th }}$ century.

In the $18^{\text {th }}-19^{\text {th }}$ centuries, church embroidery lost its connection with theology and developed under the influence of art styles of secular art. Under the influence of the Baroque style in church embroidery, the artistic effect over the content began to dominate. At the same time, Christianity entered the way of life of the people and church embroidery comes closer to the art of secular and folk embroidery. The introduction of secular embroidery into church embroidery lead to the erosion of the canon in which church embroidery existed during its golden period. Despite the commonness of the material and techniques, folk and ecclesiastical art have different content. Folk embroidery conveys, above all, the beauty of the material world; it uses a variety of techniques and materials.

The decline of official icon painting under the influence of secular painting and eclecticism caused changes in the art of church embroidery. The iconographic image method used in the ancient Russian embroidery was replaced by a pictorial one - instead of an embroidered image, faces were painted. The technique of applique from paper-mache entered the practice of church embroidery; the faces of the saints acquired volume and external beauty. The development of industry in the $19^{\text {th }}$ century made it possible to widely use such types of gold threads as gimp, truncal, beat, as well as chenille, foil, crystals and glass ${ }^{1}$. In 1848 , the Moscow firm "P. I. Olovyashnikov and Sons" was founded - the largest enterprise in Russia producing church art and handmade brocade, which contributed to the unification of church embroidery.

In the first half of the $19^{\text {th }}$ century, under the influence of secular art of beaded embroidery, vestements covered with small beads appeared among the works of the church. Most of them came from monastery workshops, but items were created by the general population. Covering the icon's vestement with small beads is a typical example of decorating church shrines, in which new materials and interpretation of the face, typical for the $19^{\text {th }}$ century, are combined with Old Russian embroidery technique in the couching [6, p. 179].

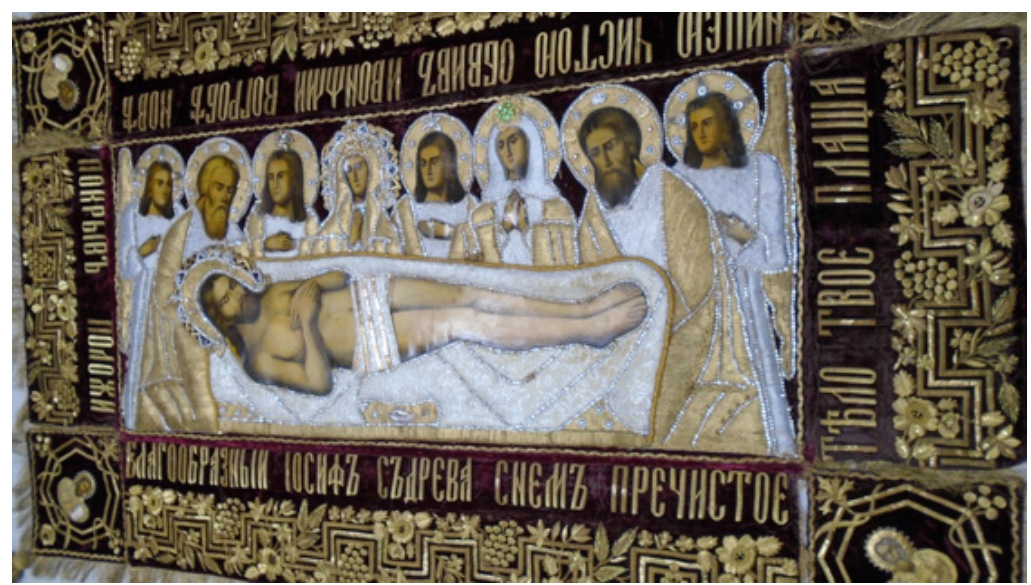

Рисунок 3 - Плащаница Господская (общий вид). XIX в. (ткань, литография, золотная нить, шитье по карте, шов в прикреп, кованый шов, канитель, бить, пайетки, стразы). $165 \times 115$.

Челябинск. Храм Святого Симеона Верхотурского

Figure 3 - Shroud of the Lord (general view). $19^{\text {th }}$ century. (fabric, lithography, gold thread, gimp, silver thread, cut glass). $165 \times 115$. Chelyabinsk. Temple of St. Simeon of Verkhoturye

${ }^{1}$ Cannetille (gimp) - thin metal wire tightly wound into a spiral. In the $18^{\text {th }}-19^{\text {th }}$ centuries, this material was widely used for making vestments, church embroidery items, and secular embroidery. 
The tradition of decorating icons' vestments has been developed throughout the Eastern Christian world and especially widely in Russia. The background of ornate icons is associated with the practice of worshiping shrines. The synthesis of pagan and peasant church images is an expression of the popular ideal of calocagacy. In the $18^{\text {th }}$ century, metal covers on the images of the Mother of God gave way to sewn vestments. Along with the traditional methods of decorating the sacred image, new ways of joining the metal vestments with embroidery and pearls appeared [7].

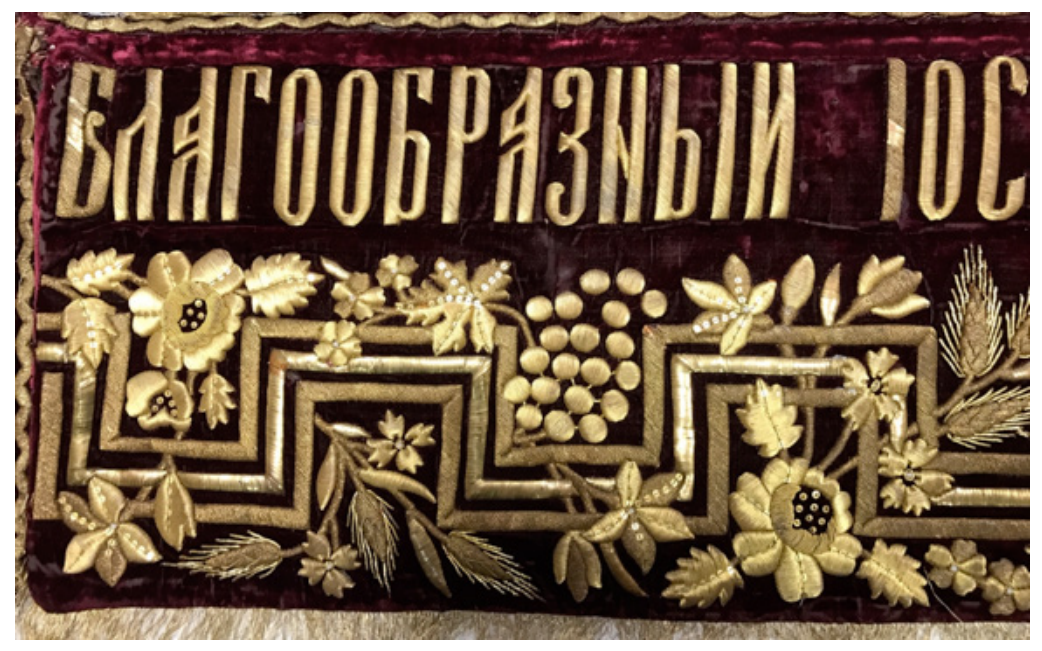

Рисунок 4 - Плащаница Господская (фрагмент каймы 1-2)

(бархат, золотная нить, шитье по карте, канитель, бить, пайетки). Челябинск

Figure 4 - Shroud of the Lord (fragment of the rim 1-2).

(velvet, gold thread, embroidery on board, gimp, sequins) Chelyabinsk

Beads and bugles were used particularly widely in church embroidery at the end of the $19^{\text {th }}$ century under the influence of the "Russian style" and historicism. In addition, the style of sewn vestments of icons was influenced by peasant art, merchant life, and the culture of the Old Believers of the North, the Volga region, and the Urals, where Old Believer iconography arose. Ural region museums house Theotokos icons of Nevyansky workshops. The exquisite beaded garment imitates the precious vestments of ancient Russian icons. Usually precious decorations were given to small home images of the Mother of God. This is especially true of the icons of Our Lady of Kazan, which is associated with the legend of its acquisition, when the miraculous image appeared in Kazan [7, p. 107-119].

The icon of Odigitria Kazan can serve as an example of "decorated" icons. (figure 1). This icon comes from the gold embroidery workshop of the Odigitrievsky Chelyabinsk monastery and was a gift from the nuns of the monastery to the archpriest V. V. Nikolsky, as evidenced by the inscription on the metal plate. Thanks to the inscription, we know that the icon was made in 1911. The faces in the icon is painted in a picturesque, academic manner. Ornamental gold embroidery in the "fastening" completely covers the robe of the Mother of God and the infant Christ. The contours, folds, and details of the robe are edged with rhinestones. The jagged edges of the crowns of Our Lady and of Christ are outlined with crocheting and decorated with faceted glass and sparkles. The shaded pattern of the "radiant" crown of the Mother of God is analogous to the crowns of precious metals on Russian icons of the $16^{\text {th }}$ and the end of the $19^{\text {th }}$ century, excluding the era of Classicism, in 
which the crowns have a scant pattern on the smooth background of the metal. In the opinion of A. V. Ryndina, "radiant" crowns among icons are the result of the individual motifs of the Catholic congregation of Loreto Madona seeping in to religious Russian art [7, p. 108]. To this we should add that this complex shape of the crown allows us to talk about the influence of jewelry art and methods of processing precious metals on the art of embroidery.

There is a shroud housed in the sacristy of the Simeon's Church which was also likely created in the gold embroidery workshop of the Odigitrievsky Monastery, about which there is little archival data. With the limited data, it was possible to establish that the gold embroidery, linen, and flower workshop were organized by the Abbess Raphaela, who was appointed abbess of the monastery in 1879. An icon painting workshop existed from the 1890s. At the end of the century, eight nuns were employed in the gold embroidery workshop of the monastery, among them - Yevgeny Sevastyanov, Alexander Ilyin, and Evdokia and Pelagia Legotine [1, p. 367].

In the second half of the $19^{\text {th }}$ century, numerous women's and men's communities appeared. Within women's monasteries, gold embroidery workshops were created. Many monasteries embroidered festive clothing, which in turn promoted the spread of gold embroidery in the common peasant society. It was in such a cultural environment that the school of gold embroidery in Torzhok was grounded.

An example of gold embroidery created based on motives of the Torzhok craft is the afore-mentioned Shroud of Lord, which is now kept in the sacristy of the Simeon temple (figure 4); the shroud has traces of restoration in the centerpiece.

The "shroud" is a large cloth with a pictorial image of an iconographic story in the centerpiece and an ornamental composition on the rim, with the text of a hymn performed during the removal of the shroud. The shroud is of Byzantine origin. Historically, shroud formed from veils. The terms "veil" and "shroud" were long used as synonyms [8].

Veils have been used in the morning service of the Great Sabbath since the $18^{\text {th }}$ century. It is in this time period that the tradition of the image of a dead Christ on a grave stone with angels on the veil and the depiction of evangelists in the corners of the object was established. After the adoption of the Jerusalem Charter of Patriarch Joachim (1681) and Patriarch Adrian (1695) in Rus, pre-Easter service traditions include the removal of a shroud from the altar and placing it on the "Holy Sepulcher". Although the iconography of the Shroud was formed based on the Lamentation and Burial of the Lord, shrouds with the scene of the Lamentation of Christ spread in Russia, and most often the embroiderers chose this scene in particular. This can serve as a confirmation that the shrouds were created with the purpose of forgiving the mother for pardoning and preserving the life and health of her sons [4, p. 196]. The centerpiece of the shroud was decorated with a border which complemented its sense and. At the heart of the most ancient ornament that adorned the rim was the image of a cross inscribed in interlacing circles. In the $15^{\text {th }}$ century, veils with a textual border ornamentation were created. By the end of the 16th century, a stylized vine motif appeared on the edges, inscribed in quadrifolium or in combination with lily.

There are a few types of iconographic shrouds. The sacristy of the Simeon temple houses a liturgical-historical type of the Shroud of the Lord (figure 3). The centerpiece of the veil depicts Christ on a grave stone, above it — the Virgin with a myrrh-bearer, apostles, Joseph of Arimathea, Nicodemus, and angels. The figure of Christ lying on the bed, and the images of the saints are created through voluminous application of brocade silvery (restoration); the faces of the saints - through painting on cardboard, surrounded by nimbuses, decorated with 
rhinestones. Using a picturesque image to depict the faces of saints instead of an embroidered image reflects the trends of church art of the late $19^{\text {th }}$ century. On the cherry velvet rims of the shroud, the artists used gold embroidery on cardboard to add liturgical text: "A good Joseph, from the tree with a dream. Your pure body, wrapping the puree with a clean cloth and stenching in the coffin" (Troparion, Tone 2). The beautiful, clear ligatured script of the inscription on the border forms a wide ornamental frame. The inscription is not the only decorative element. On the cherry velvet, there is gold embroidered ornamentation consisting of stylized flowers of cloves, grapes, and wheat ears. The four corners of the shroud image show the Evangelists with overlaid faces in an octagonal form. The manner of embroidery, the methods of conveying the volume (embroidery on board), and the ways of depicting the motif of the grapes and wheat ears (using a "molten" seam and gimp imitating the hairs characteristic of oats) - allows us to attribute this shroud to the end of the $19^{\text {th }}$ century.

The symbolic image of grapes was present in church art in the carvings of iconostases and in the ornament of church embroidery. With the approval of those in Orthodoxy, the image of grapes spread in folk art on festive women's clothing and in picturesque painting on wood.

In addition to the grape motive, the ornamental elements of the shroud embroidery also include peony and carnations, which were popular in Iranian art. The peonies are made of gold thread by a cast seam, which gives embroidery a special relief, and the middle of the flower is highlighted with gimp (figure 4).

To reproduce the lush colors and leaves of a complex pattern, various strings of gold thread and embroidery techniques are used in the ornamentation to create a precious, nuanced texture. The richness of the decor is also achieved through the introduction of gold sequins, beads, and gimp. All of the flora and geometric elements of the ornamentation of the shroud are mutually balanced on the plane, are subordinate to the internal rhythm, and are combined with the textual border and the background. The ornamental border of dark cherry velvet surrounds the centerpiece of the shroud, strengthening the decorative side of the ornament and even prevailing over the centerpiece image. The techniques used, especially the principle of the crown of the Mother of God (with characteristic barbs) allow us to hypothesize and correlate the shroud we examined with the gold embroidery workshop of the Chelyabinsk Odigitrievsky Monastery. This shroud is a work of decorative ornamental embroidery designed to create the impression of solemnity in the interior of the temple. Simultaneously, being a Christian relic, the shroud participates in the organization of the sacred space of the Eastern Christian church.

We considered artifacts of church embroidery of the $19^{\text {th }}$ - early $20^{\text {th }}$ century. The role of monastic workshops in preserving the traditions of folk art and decorative and applied art, their functional applied and artistic features, as well as the significance of this art form in the context of the artistic activity of the monasteries of the Urals was established. We showed that the objects of the church that emerged from the monastic workshops in the $19^{\text {th }}$ and early $20^{\text {th }}$ centuries are artistic and historical artifacts of that time. In conclusion, it should be said that the published artifacts of artistic embroidery reveal tendencies in the aestheticization of church art in the spirit of their time. On the one hand, the artifacts bear the ancient Russian traditions of ornamentation, on the other, they express the influence of secular and folk art, the culture of the Old Believers, and a certain desire to standardize church embroidery in the second half of the $19^{\text {th }}$ century. As a result of our research, certain artifacts of church embroidery which reveal the historical, theological, and artistic features of Russian church embroidery of the $19^{\text {th }}$ century are introduced into scientific circulation. 


\section{СПИСОК ЛИТЕРАТУРЫ}

1 Алферов Д. Г. Монахини и послушницы Челябинского женского Одигитриевского монастыря // Челябинск неизвестный: краевед. сб. Челябинск: Центр ист.культур. наследия г. Челябинска, 2008. Вып. 4. С. 366-388.

2 Азаров A. A. Русско-английский энциклопедический словарь искусств и художественных ремесел. В 2 т. T. 2. // E.lanbook.com. URL: https://e.lanbook.com/ book/51799 (дата обращения: 31.01.2019).

3 Козлякова Н. В. Художественная вышивка: орнаментальное золотное шитье: уч.метод. пособие. Магнитогорск: Изд-во МаГУ, 2009. 140 с.

4 Круглова A. Р. Золотошвейное рукоделие великокняжеских и царских мастерских XV-XVI веков. СПб.: Коло, 2011. 288 с.

5 Маясова Н. А. Древнерусское шитье. М.: Искусство, 1971. 57 с.

6 Моисеенко Е. Ю., Фалеева В. А. Бисер и стеклярус в России XVIII - начало XX в. Л.: Художник РСФСР, 1990. 200 с.

7 Русское церковное искусство Нового времени = Russian ecclesiastical art modern times / сост. А. В. Рындина и др. М.: Индрик, 2004. 320 с.

8 Троицкий В. История плащаницы. Сергиев Посад. 1913 // Predanie.ru. URL: http:// predanie.ru/ilarion-troickiy-svyaschennomuchenik/book/72267-istoriya-plaschanicy (дата обращения: 31.01.2019).

9 Хребина Т. В. Церковное шитье: традиции и современность: дис. ... канд. искусствоведения. СПб., 2007. 380 с.

\section{REFERENCES}

1 Alferov D. G. Monakhini i poslushnitsy Cheliabinskogo zhenskogo Odigitrievskogo monastyria [Nuns and novices of the Chelyabinsk women's Odigitrievsky monastery]. In: Cheliabinsk neizvestnyi: kraevederdcheskii sbornik [Unknown Chelyabinsk: local history collection]. Cheliabinsk, Tsentr istorichesko-kul'turnogo naslediia g. Cheliabinska Pubbl, 2008, vol. 4, pp. 366-388. (In Russian)

2 AzarovA.A.Russko-angliiskiientsiklopedicheskiislovar' iskusstvikhudozhestvennykh remesel. V 2 t. T. 2. [Russian-English encyclopedic dictionary of arts and crafts. In 2 vols. Vol. 2]. In: E.lanbook.com. Available at: https://e.lanbook.com/book/51799 (accessed 31 January 2019). (In Russian)

3 Kozliakova N. V. Khudozhestvennaia vyshivka: ornamental'noe zolotnoe shit'e: uchebnoe metodicheskoe posobie [Artistic embroidery: ornamental gold embroidery: a textbook]. Magnitogorsk, Izdatel'stvo MaGU Publ., 2009. 140 p. (In Russian)

4 Kruglova, A. R. Zolotoshveinoe rukodelie velikokniazheskikh i tsarskikh masterskikh $X V-X V I$ vekov [Gold-embroidered needlework of the Grand-Ducal and Royal workshops of the $15^{\text {th }}-16^{\text {th }}$ centuries]. St. Petersburg, Kolo Publ., 2011. 288 p. (In Russian)

5 Maiasova N. A. Drevnerusskoe shit'e [Old Russian sewing]. Moscow, Iskusstvo Publ., 1971. 57 p. (In Russian)

6 Moiseenko E. Iu., Faleeva V. A. Biser i stekliarus $v$ Rossii XVIII-nachalo XXv. [Beads and glass beads in Russia in the $18^{\text {th }}-$ early $20^{\text {th }}$ century]. Leningrad, Khudozhnik RSFSR Publ., 1990. 200 p. (In Russian)

7 Russkoe tserkovnoe iskusstvo Novogo vremeni $=$ Russian ecclesiastical art modern times [Russian ecclesiastical art Modern times], compiled by A. V. Ryndin and other. Moscow, Indrik Publ., 2004. 320 p. (In Russian) 
8 Troitskii V. Istoriia plashchanitsy. Sergiev Posad. 1913 [History of the shroud. Sergiev Posad. 1913]. In: Predanie.ru. Available at: http://predanie.ru/ilarion-troickiysvyaschennomuchenik/book/72267-istoriya-plaschanicy (accessed 31 January 2019). (In Russian)

9 Khrebina T. V. Tserkovnoe shit'e: traditsii i sovremennost' [Church sewing: traditions and modernity: PhD Dissertation]. St. Petersburg 2007. 380 p. (In Russian) 